\title{
A Study of the Subjectification of the Chinese Word Suoyi
}

\author{
Qingshun He \\ Faculty of English Language and Culture, Guangdong University of Foreign Studies, Guangzhou, China \\ Email: markman1998@163.com
}

Received 29 May 2014; revised 5 July 2014; accepted 13 July 2014

Copyright (C 2014 by author and Scientific Research Publishing Inc. This work is licensed under the Creative Commons Attribution International License (CC BY). http://creativecommons.org/licenses/by/4.0/

c) (i) Open Access

\begin{abstract}
Subjectivity is an essential characteristic of language. In recent years, the subjectivity of language has been attracting the attention of the linguists. Two main research strains have developed, one being represented by Langacker, and the other by Traugott. The former studies subjectivity synchronically from a cognitive perspective, noting that in addition to the proposition meaning, language also expresses the speaker's attitude, while the latter studies the process of subjectification from a diachronic perspective, pointing out that language tends to evolve from objectivity to subjectivity. Taking the Chinese word suoyi as an example, this research studies the process of subjectification, finding that the grammaticalization of suoyi has gone through three stages from a prepositional phrase through a causal conjunction to a discourse marker. In this three-stage process, the conceptual meaning has been declining, and the procedural meaning and the subjectivity have been strengthened.
\end{abstract}

\section{Keywords}

Subjectivity, Subjectification, Grammaticalization, Suoyi, Discourse Marker

\section{Introduction}

For a good part of the $20^{\text {th }}$ century, structural linguistics has dominated other schools of linguistics, and language has been considered as expressing objective propositions. However, with the development of functional linguistics, pragmatics and cognitive linguistics, the subjective characteristics of language have been attracting people's attention, and have "been seen as paramount to linguistic research" (Davidse, Vandelanotte, \& Cuyckens, 2010: p. 2). According to Shen (2001), language expresses not only the objective proposition, but also the speaker's opinion, feeling and attitude. In recent years, the study of the subjectivity of language has been conducted from various levels of language (Liu, 2009: p. 9) and has developed into a trend of synchronic study, i.e., Subjectivity, 
represented by Langacker and a trend of diachronic study, i.e., Subjectificaiton, represented by Traugott. The content of research covers syntax, deixis, time and tense, modality and discourse markers, etc.

Based on relevant theories on subjectivity and subjectification, this research intends to analyze the subjectification tendency of the Chinese word suoyi in its grammaticalization process. For this purpose, we will first offer a sketch of the subjectivity in language in Section two, distinguishing such basic concepts as subjectivity, subjectification and grammaticalization, and clarifying the unidirectionality of subjectification. In Section three, we will analyze the subjectification of the Chinese word suoyi in its grammaticalization process from a diachronic perspective.

\section{Subjectivity in Language}

\subsection{Subjectivity and Subjectification}

In everyday discourse, the speaker will express not only the propositional meaning, but also the "speakermeaning". The latter reflects the subjectivity of language. "The 'subjectivity' we are discussing here is the capacity of the speaker to posit himself as 'subject'.” (Benveniste, 1971: p. 224), i.e., the speaker's attitude and feeling towards and the "ego" left in what he is speaking (Lyons, 1977; 1982; Finegan, 1995; Traugott, 1989; 1995; Shen, 2001; Wu, 2004). Subjectification occurs when the subjectivity in language is encoded in a clear structure, or when a language form has obtained the function to express subjectivity in its evolution (Wu, 2004).

Subjectivity represents the situation affected by personal views. The study of the subjectivity of language has been conducted from a synchronic perspective and a diachronic perspective. The former views linguistic phenomena only at a given time, usually the present, though a synchronic analysis of a historical language form is also possible, and the latter, regards a linguistic phenomenon in terms of its development through time. Synchronically, the speaker or writer selects not only the content but also the ways to express the content. Any lexical or grammatical selection is speaker-involved. The selection reflects the subjectivity of language. Therefore, "the subjectivity is inherent in language" (De Smet \& Verstraete, 2006: p. 384); subjectivity makes language as it is (Liu, 2009).

Langacker (1985; 1990; 1999; 2002; 2003; 2006; 2008) studies the language subjectivity synchronically from the cognitive perspective. For example:

(1) Mary is going to close the door.

(2) An earthquake is going to/gonna destroy the city.

According to Langacker (1990), the change of the verb go from the space meaning to the time meaning to indicate the future meaning is a process of subjectification. In 1), the subject Mary is not only the one crossing the path but also the one closing the door. However, in 2), the subject An earthquake is only the agent of the action, but not the one crossing the path. That is, it is not the subject An earthquake that goes through a path, rather it is the speaker that goes through a mental path. Langacker (1990: p. 19) refers to this use as subjectification because the spatial movement of the objective participant has been replaced by the conceptualized subjective movement, i.e., the mental scanning. Therefore, the subjectivity defined by Langacker includes also the mental scanning of the situation by the speaker (Shen, 2001).

According to Langacker (2006), an expression itself has no subjective and objective distinctions. The conceptual meaning of an expression may be gradually construed with a greater degree of subjectivity or objectivity over time. The idea of subjectivity and objectivity lies in the perceptual asymmetry between the observer and the observed entity. The feature of the maximal subjectivity is the presence of the observer, and the feature of the maximal objectivity is "the focused object of attention: the entity an expression puts onstage and profiles" (Langacker, 2008: p. 77).

Traugott (1982; 1989; 1995; 1999; 2003; 2010) studies the language subjectivity from a diachronic perspective. She observes the tendency of subjectification through investigating the change of meaning. That is, how the grammatical structure or form expressing subjectivity in language evolves. According to Traugott (1989), subjectivity is a semantic process, that is, a new meaning, including the speaker reference or the speaker perspective, evolves out of a language component. According to this view, Example (1) expresses a movement, when the subject is inanimate, or when the verb is a mental one, be going to is completely grammaticalized into a time marker of future inference (Traugott, 1995).

Language is not only subjective but also intersubjective. "Intersubjectivity in my view refers to the way in which natural languages, in their structure and their normal manner of operation, provide for the locutionary 
agent's expression of his or her awareness of the addressee's attitudes and beliefs, most especially their 'face' or 'self-image'.” (Traugott, 2010: p. 33). Language is in essence dialogic and persuasive. Therefore, the use of language necessarily involves the cognitive interaction and coordination between the speaker and the addressee, hence intersubjectivity occurring. The use of the first person plural instead of the first person singular, the second person singular, or the second person plural may reflect the particular concerns of the speaker about the addressee. For example:

(3) A doctor said to a patient, "we can take eye's drops, now!”

In addition to the personal pronouns, intersubjectivity is also reflected in the following situations: discourse markers (well, in fact, indeed), parentheses (I think, I guess, I mean), polite expressions (if you please, please) and evaluative adverbs (frankly, honestly). Here are two examples given by Traugott (2003: p. 129):

(4) I will drive you to the dentist.

(5) Actually, I will drive you to the dentist.

Example (4) uses the auxiliary verb will to indicate the speaker's desire. This expresses subjectivity, but does not reflect the addressee's "face” and "self-image”. The adverb actually in (5) reflects the speaker's consideration of the addressee's “face” as well as the addressee's attention to the speaker's attitude.

\subsection{Subjectification and Grammaticalization}

Traugott (1989) discusses the interaction between grammaticalization and subjectification. Grammaticalization means the "gradual morphosyntactic and semantic change which results in grammatical reanalysis" (Tabor \& Traugott, 1998: p. 236); it is “in essence a morphosyntactic phenomenon” (Traugott \& Dasher, 2002: p. 283). For example, the evolution of while in (6) from the meaning of "at the same time" to that of concession in (7) is a process of grammaticalization, the subjectivity of the latter being stronger than the former.

(6) Mary read while Bill sang.

(7) Mary liked oysters while Bill hated them.

Subjectification usually involves and “is an important mechanism of grammaticalization” (Traugott, 1999). However, subjectification and grammaticalization are different types of changes, and they can occur independently. Subjectification is not necessarily accompanied by grammaticalization. For example, we sometimes use "pig” to describe a lazy and greedy person. Both the subjective and non-subjective uses of “pig” are lexical. Similarly, grammaticalization is not necessarily accompanied by subjectification. For example, the evolution of the preposition to into an infinitive marker, and that of by into a passive marker do not involve subjectification. For example:

(8) The hiker ran up the hill.

(9) The highway runs from the valley floor to the mountain ridge.

Example (8) is an objective description of the hiker's space movement. However, in (9), it is not the highway that is moving; rather it is the speaker that is moving along an imaginative highway, hence the subjectivity of the verb runs, which, however, is not grammaticalized at all.

\subsection{Unidirectionality of Subjectification}

Traugott (1989) and Langacker (1990) both consider subjectification as a unidirectional process. The former emphasizes the function, holding that the process of subjectification is that of the gradual encoding of the form or structure of the objective function into the speaker-centred discourse function. The latter emphasizes the construal, holding that certain aspects of the discourse events can be construed with more or less subjectivity, and the lower the level of consciousness, the higher the level of subjective construal.

Traugott (1982) substitutes propositional, textual and expressive components for the ideational, textual and interpersonal components in Systemic Functional Linguistics. What she is concerned about is how a lexical item originated from the ideational domain evolves into multiple meanings and then enters into the textual and interpersonal domains. She argues that "meaning change is essentially a unidirectional process of subjectification which typically proceeds along the following pathway: propositional (>textual) > expressive” (Traugott, 1982: p. 256).

Let's take while as an example. In old English, while means "at the time that”, referring to time as part of the verifiable propositional content. In the middle ages, while means "during", referring to not only the cohesion between two events but also that between two clauses. In modern English, while means “although”, expressing 
the attitude of the speaker. Thus, while has gradually been subjectified from the propositional meaning through the textual meaning to the expressive meaning. The evolution of any grammatical marks is unidirectional, but "not in the reverse direction" (Fanego, 2010: p. 201). The change of the aspect from expressing result to expressing completeness is a process of subjectification. At each stage of this process, the result is less and less dependent on the objective fact, and is more and more dependent on the attitude and judgment of the speaker. At the initial stage, the result is entirely dependent on the meaning of the participle, and at the final stage, the relevant relationship between the event and the present time is completely a matter of subjective judgment.

Subjectification is a pragmatic-semantic evolution process (Traugott, 1995). Most new meanings are developed as polysemy, from pragmatic meaning to semantic meaning. For example, Traugott \& Dasher (2002) divide the semantic evolution of must into three stages: 1) must had the original meaning of ability and permission; 2) In the latter half of the old English, must gained a deontic meaning of obligation; 3) In the mid-middle ages, must developed epistemic meaning. The deontic use of must emerged at the second stage when 'no social, religious, or other normative force is specified or implied' (Traugott \& Dasher, 2002: p. 125). That is, at this stage, it is the modal force itself that is used as a measure of subjectivity.

De Smet \& Verstraete (2006) distinguish three types of subjectivity, including one type of pragmatic subjectivity and two types of semantic subjectivity, i.e., the ideational and interpersonal subjectivity. Pragmatic subjectivity is about the speaker's use of language symbols, ideational subjectivity involves the description of the content, roughly equivalent to Traugott's (1989: p. 34) internal propositional meaning, and the interpersonal subjectivity refers to the expression enacting the speaker's position on a particular content, such as deontic and epistemic auxiliaries, discourse markers, illocutionary speech acts, modal adverbs and intensifying adjectives, etc.

Pragmatic subjectivity will not necessarily develop into semantic subjectivity. Even if the pragmatic subjectivity were developing towards the semantic subjectivity, it would not possibly develop into interpersonal subjectivity. For example, both since and after are causal conjunctions, the former having been semanticized, but the latter not.

Schwenter \& Waltereit (2010) conduct a study of the development path of too from additive use (ideational meaning) to independent use (interpersonal meaning). For example:

(10) John had ice cream, and Mary had ice cream too.

(11) A: You didn’t do your homework!

B: I did too!

The additive too in (10) connects two paralleled propositions at the ideational domain. Both the two propositions answer the question Who had ice cream? In (11), speaker A said that B did not do his homework, but speaker B denied A's proposition, claiming that he in fact did his homework. Here, too is a used independently, meaning "to refute", hence the transfer from the ideational meaning to the interpersonal meaning.

In order to fully reveal the nature of semantic change, Ghesquière (2010: p. 309) adds Traugott's (2003) intersubjectification dimension into her (Traugott, 1982) semantic change model, and divides the propositional meaning proposed by Traugott (1982) into external proposition and internal proposition. The external proposition realizes the objective description and the internal proposition, the subjective description. Therefore, Ghesquière (2010) proposes the following semantic change model. See Figure 1.

From a diachronic perspective, intersubjectification develops from subjectification, because in general epistemic meaning typically precedes inferential meaning. In other words, if a language form is intersubjective, it must be subjective (Wu, 2004).

\section{A Case Study}

With the in-depth study of the language subjectivity, Chinese scholars have begun to carry out research on the

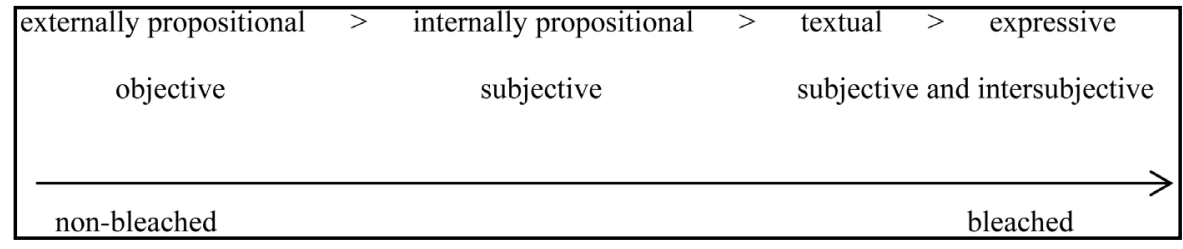

Figure 1. Model of semantic change. 
subjectivity of the Chinese languege (e.g. Shen, 2001; Zhang, 2010). In this section, we will study the subjectification of the Chinese word suoyi in its grammaticalization process from a diachronic perspective.

Suoyi began to be fixed in the Zhou Dynasty (1046 BC-771 BC), and was widely used in the Spring and Autumn Period (770 BC-476 BC). For example:

(12) 忠信, 所以进德也; 修辞立其诚, 所以居业也。《周易》

(13) 夫义所以生利也, 祥所以事神也, 仁所以保民也。《国语》

(14) 博厚, 所以载物也; 高明, 所以覆物也; 悠久, 所以成物也。《礼记》

In these examples, suo is used as a noun, meaning "location”, and yi, after being bleached from a verb into a preposition, expresses the meaning of "by virtue of". Suo and yi together form a prepositional phrase, meaning "a place for doing something". It is often closely followed by a verbal group, functioning as an element of the clause.

During the Warring States Period (475 BC-221 BC), suoyi was further bleached from a prepositional phase into a solidified conjunction. The conjunction suoyi expresses the result or conclusion in the causal relationship (Lu, 1980: 457). This usage gradually matured in the Western Han Dynasty (206BC-AD25). For example:

(15) 君不此问, 而问舜冠, 所以不对也。《荀子.哀公》

(16) 名亦既有, 天亦将知之, 知之所以不待。《道德经 . 圣德》

(17) 臣闻晏子事三君而得顺焉, 是有三心, 所以不见也。 《晏子春秋》

In this period, the referential function of suo disappeared, and suoyi is no longer used as a prepositional phrase to function as an element of the clause; it plays only the role of a conjunction.

The phrase yinwei/youyu..., suoyi was fixed in the Ming Dynasty (1368-1644) where suoyi functions as a conjunction of result. Such a sentence pattern generally expresses a causal relationship, that is, talking about the cause of a completed event (Xing, 2001: 59; Yao, 2009). Here are some examples:

(18) 小尼也曾问来, 学士回说道: “因为访亲, 所以改换名姓。” 《二刻拍案惊奇 (上)》

(19) 只因为你两个名誉未成, 使我作违心之事, 冒不韪之名, 有玷于祖宗, 贻笑于乡里, 所以流泪。 《今古奇观 (上)》

(20) 九弟前病时想回家, 近来因为找不到好伴, 并且听说路上不平安, 所以已不准备回家了。《曾 国藩家书》

This structure is also popularly used in modern Chinese. For example:

（21）他是搞摇滚的, 因为在家排行老五, 所以大家都叫他小五。《中国北漂艺人生存实录》

(22) 由于距离太阳十分遥远, 所以它从太阳得到的热量极其微弱。《中国儿童百科全书》

In modern Chinese, either yinwei or suoyi can be omitted with the meaning unchanged. Although the causal relationship still exists, the speaker's attitude has already been included. For example:

(23) 莘善因为自家无子, 要寻个养女婿来家靠老。《今古奇观 (上)》

(24) 圆明园是圆明、长春、万春三园的总称，所以也叫 “圆明三园”。《中国儿童百科全书》

The speaker's attitude is more popularly reflected in the inferential suoyi clauses. Here, the suoyi clause has not necessarily a direct causal relationship with the preceding clause, but the two clauses have an argumentative relationship (Liao, 1992; Fang, 2000). At this time, suoyi is different from its original meaning. Inference is in essence of strong subjectivity, and hence some modality markers of subjectivity are usually used (Yao, 2009). For example:

（25）这次和谈的气氛比上次好得多, 各方代表之间也更加友好, 所以, 我们肯定会达成某种协议, 结束在我们土地上的流血冲突。《新华社 2004 年新闻稿_004》

(26) 由此可见, 念佛时, 心要忆佛念佛。切不可散心口念而心不忆佛, 所以, 一心不乱是很重要的。 《佛法修正心要》

Even if there is no direct causal relationship with the preceding clause, the suoyi clause can also be used to express the speaker's evaluation of the event. This usage is very common in dialogue (Yao, 2009), because dialogues are always on-site and commentary. For example: 
（27）他们把几十万华北国民党军队驱赶得望风而逃。所以, 平型关大捷意义非常重大。 《中共十大 元帅》

(28) 我都不敢相信这么多人是来欢迎我们的。所以说还是回家好啊！ 《新华社 2004 年新闻稿》

With the further weakening of meaning, suoyi has been gradually losing its logical conceptual meaning, leaving only the procedural meaning, and becoming a discourse marker. The meaning of discourse markers is procedural, not conceptual (Fraser \& Malamud-Makowski, 1996; Fraser, 1999). For example:

(29) 王有龄向他托孤的话, 原是为了征信之用; 现在王有龄既已相信自己的身分, 这话就不必再提, 免得惹他伤心，所以接下来便谈正题。《红顶商人胡雪岩》

The conjunction suoyi used as a discourse marker occurs mainly in spoken language. It has no propositional content and functions mainly as a textual cohesion device or to express the speaker's attitude. Therefore, "discourse markers are subjectified expressions” (Traugott \& Dasher, 2002: p. 152).

（30）这个, 这个旧的习惯吧, 过这个腊八, 喝这腊八粥, 平时就爱说, 腊八腊八冻死俩仁儿, 什么 哪, 就是最冷的时候, 也就是说乞灭什么的, 在那时侯最容易冻死在大街上, 腊八腊八冻死俩仁儿, 所 以就是家家都要㥿腊八粥。 《1982 年北京话调查资料》

Discourse markers indicate the speaker's position, or the addressee's role in the conversation. They have no conceptual meaning, and so they contribute little to the truth value of the propositional meaning. They indicate the speaker's view on the sequential relations between the discourse components. Removing the discourse marker suoyi in the above example sentences will not affect the logical relationship of context, but the addressee will have to pay more cognitive effort.

\section{Conclusion}

Subjectivity is essential to language and language has the tendency to evolve from objectivity to subjectivity. Our demonstration research shows that suoyi can express both the logical conceptual meaning and the procedural meaning. When expressing the procedural meaning, it does not convey the propositional truth value, but is used as a discourse marker. The evolution of suoyi from a prepositional phrase through a causal conjunction to a discourse marker is a process of gradual grammaticalization. In this process, the propositional meaning of suoyi has been bleached, and the speaker's attitude meaning has been strengthened. At the stage of the clausal conjunction, suoyi can express not only the conceptual meaning but also the procedural meaning. When it expresses the inferential meaning, subjectivity begins to occur, and when it expresses the evaluation meaning, the subjectivity is strengthened. At the discourse marker stage, suoyi has completely lost its conceptual meaning, and is completely grammaticalized, hence intersubjectivity occurring.

\section{References}

Benveniste, E. (1971). Subjectivity in Language. In: M. E. Meek (Ed.). Problems in General Linguistics (pp. 223-230). Coral Gables: FL: University of Miami Press.

Davidse, K., Vandelanotte, L., \& Cuyckens, H. (Eds.). (2010). Subjectification, Intersubjectification and Grammaticalization. Berlin \& New York: Mouton de Gruyter. http://dx.doi.org/10.1515/9783110226102

De Smet, H., \& Verstraete, J.-C. (2006). Coming to Terms with Subjectivity. Cognitive linguistics, 3, 365-392.

Fanego, T. (2010). Paths in the Development of Elaborative Discourse Markers: Evidence from Spanish. In: K. Davidse, L. Vandelanotte, \& H. Cuyckens (Eds.). Subjectification, Intersubjectification and Grammaticalization (pp. 197-237). Berlin \& New York: Mouton de Gruyter. http://dx.doi.org/10.1515/9783110226102.2.197

Fang, M. (2000). Reduced Conjunctions as Discourse Markers. Studies of the Chinese Language, 5, 459-470.

Finegan, E. (1995). Subjectivity and Subjectivisation: An Introduction. In: D. Stein, \& S. Wright (Eds.). Subjectivity and Subjectivisation (pp. 1-15). Cambridge: Cambridge University Press.

http://dx.doi.org/10.1017/CBO9780511554469.001

Fraser, B. (1999). What are Discourse Markers? Journal of pragmatics, 31, 931-952.

http://dx.doi.org/10.1016/S0378-2166(98)00101-5

Fraser, B., \& Malamud-Makowski, M. (1996). English and Spanish Contrastive Discourse Markers. Language Sciences, 18, 863-881. http://dx.doi.org/10.1016/S0378-2166(98)00101-5 
Ghesquière, L. (2010). On the Subjectification and Intersubjectification Paths Followed by the Adjectives of Completeness. In: K. Davidse, L. Vandelanotte, \& H. Cuyckens (Eds.). Subjectification, Intersubjectification and Grammaticalization (pp. 277-314). Berlin \& New York: Mouton de Gruyter. http://dx.doi.org/10.1515/9783110226102.3.277

Langacker, R. W. (1985). Observations and Speculations on Subjectivity. In: J. Haiman (Ed.). Iconicity in Syntax (pp. 109-150). Amsterdam \& Philadelphia: Benjamins. http://dx.doi.org/10.1075/tsl.6.07lan

Langacker, R. W. (1990). Subjectification. Cognitive linguistics, 1, 5-38. http://dx.doi.org/10.1515/cogl.1990.1.1.5

Langacker, R. W. (1999). Losing Control: Grammaticalization, Subjectification, and Transparency. In: A. Blank, \& P. Koch (Eds.), Historical Semantics and Cognition (pp. 147-175). Berlin \& New York: Mouton de Gruyter. http://dx.doi.org/10.1515/9783110804195.147

Langacker, R. W. (2002). Deixis and Subjectivity. In: F. Brisard (Ed.), Grounding: The Epistemic Footing of Deixis and Reference (pp. 1-28). Berlin \& New York: Mouton de Gruyter. http://dx.doi.org/10.1515/9783110899801.1

Langacker, R. W. (2003). Extreme Subjectification: English Tense and Modals. In: H. Cuyckens, T. Berg, R. Dirven, \& K. U. Panther (Eds.), Motivation in Language: Studies in Honor of Günter Radden (pp. 3-26). Amsterdam \& Philadelphia: Benjamins. http://dx.doi.org/10.1075/cilt.243.05lan

Langacker, R. W. (2006). Subjectification, Grammaticization, and Conceptual Archetypes. In: A. Athanasiadou, C. Canakis, \& B. Cornillie (Eds.), Subjectification: Various Paths to Subjectivity (pp. 17-40). Berlin \& New York: Mouton de Gruyter. http://dx.doi.org/10.1515/9783110892970.17

Langacker, R. W. (2008). Cognitive Grammar: A Basic Introduction. Oxford: Oxford University Press. http://dx.doi.org/10.1093/acprof:oso/9780195331967.001.0001

Liao, Q. (1992). Connecting Components in Modern Chinese Texts. In: Q. Liao (Ed.), Collected Works of Liao Qiuzhong (pp. 62-91). Beijing: Beijing Language and Culture University Press.

Liu, J. (2009). A Discussion of the Interpretations of Linguistic Subjectivity. Journal of Xi'an International Studies University, 3, 39-42.

Lu, S. (1980). Eight Hundred Words of Modern Chinese Language. Beijing: The Commercial Press.

Lyons, J. (1977). Semantics. Vol. 2, Cambridge: Cambridge University Press.

Lyons, J. (1982). Deixis and Subjectivity: Loquor, Ergo Sum? In: R. J. Jarvella, \& W. Klein (Eds.), Speech, Place, and Action: Studies in Deixis and Related Topics (pp. 101-124). Chichester \& New York: John Wiley.

Schwenter, S. A., \& Waltereit, R. (2010). Presupposition Accommodation and Language Change. In: K. Davidse, L. Vandelanotte, \& H. Cuyckens (Eds.), Subjectification, Intersubjectification and Grammaticalization (pp. 75-102). Berlin \& New York: Mouton de Gruyter. http://dx.doi.org/10.1515/9783110226102.2.75

Shen, J. (2001). A Survey of Studies on Subjectivity and Subjectivisation. Foreign Language Teaching and Research, 4, 268-275.

Tabor, W., \& Traugott, E. C. (1998). Structural Scope Expansion and Grammaticalization. In: A. G. Ramat, \& P. J. Hopper (Eds.), The Limits of Grammaticalization (pp. 229-272). Amsterdam \& Philadelphia: Benjamins. http://dx.doi.org/10.1075/tsl.37.11tab

Traugott, E. C. (1982). From Propositional to Textual and Expressive Meanings: Some Semantic-Pragmatic Aspects of Grammaticalization. In: W. P. Lehmann, \& Y. Malkiel (Eds.), Perspectives on Historical Linguistics (pp. 245-271). Amsterdam \& Philadelphia: Benjamins.

Traugott, E. C. (1989). On the Rise of Epistemic Meanings in English: An Example of Subjectification in Semantic Change. Language, 65, 31-55. http://dx.doi.org/10.2307/414841

Traugott, E. C. (1995). Subjectification in Grammaticalization. In: D. Stein, \& S. Wright (Eds.). Subjectivity and Subjectivisation: Linguistic Perspectives (pp. 31-54). Cambridge: Cambridge University Press.

http://dx.doi.org/10.1017/CBO9780511554469.003

Traugott, E. C. (1999). The Rhetoric of Counter-Expectation in Semantic Change: A Study in Subjectification. In: A. Blank, \& P. Koch. (Eds.), Historical Semantics and Cognition (pp. 61-89). Berlin \& New York: Mouton de Gruyter. http://dx.doi.org/10.1515/9783110804195.177

Traugott, E. C., \& Dasher, R. B. (2002). Regularity in Semantic Change. Cambridge: Cambridge University Press.

Traugott, E. C. (2003). From Subjectification to Intersubjectification. In: R. Hickey (Ed.), Motives for Language Change (pp. 124-139). Cambridge: Cambridge University Press.

Traugott, E. C. (2010). (Inter)subjectivity and (Inter)subjectification: A Reassessment. In: K. Davidse, L. Vandelanotte, \& H. Cuyckens (Eds.), Subjectification, Intersubjectification and Grammaticalization (pp. 29-71). Berlin \& New York: Mouton de Gruyter. http://dx.doi.org/10.1515/9783110226102.1.29 
Wu, F. (2004). Recent Studies on Grammaticalization. Foreign Language Teaching and Research, 1, 18-24.

Xing, F. (2001). The Research on Chinese Sentences with Two or More Clauses. Beijing: The Commercial Press.

Yao, S. (2009). Semantic Reduction and Function Expansion of "Suoyi” in Spoken Chinese. Chinese Linguistics, 3, 16-23.

Zhang, Y. (2010). A Semantics-Syntax Interface Study of SoA Qualification-Based on Cognitive Intersubjectivity. Foreign Language Teaching and Research, 3, 203-210. 
Scientific Research Publishing (SCIRP) is one of the largest Open Access journal publishers. It is currently publishing more than 200 open access, online, peer-reviewed journals covering a wide range of academic disciplines. SCIRP serves the worldwide academic communities and contributes to the progress and application of science with its publication.

Other selected journals from SCIRP are listed as below. Submit your manuscript to us via either submit@scirp.org or Online Submission Portal.
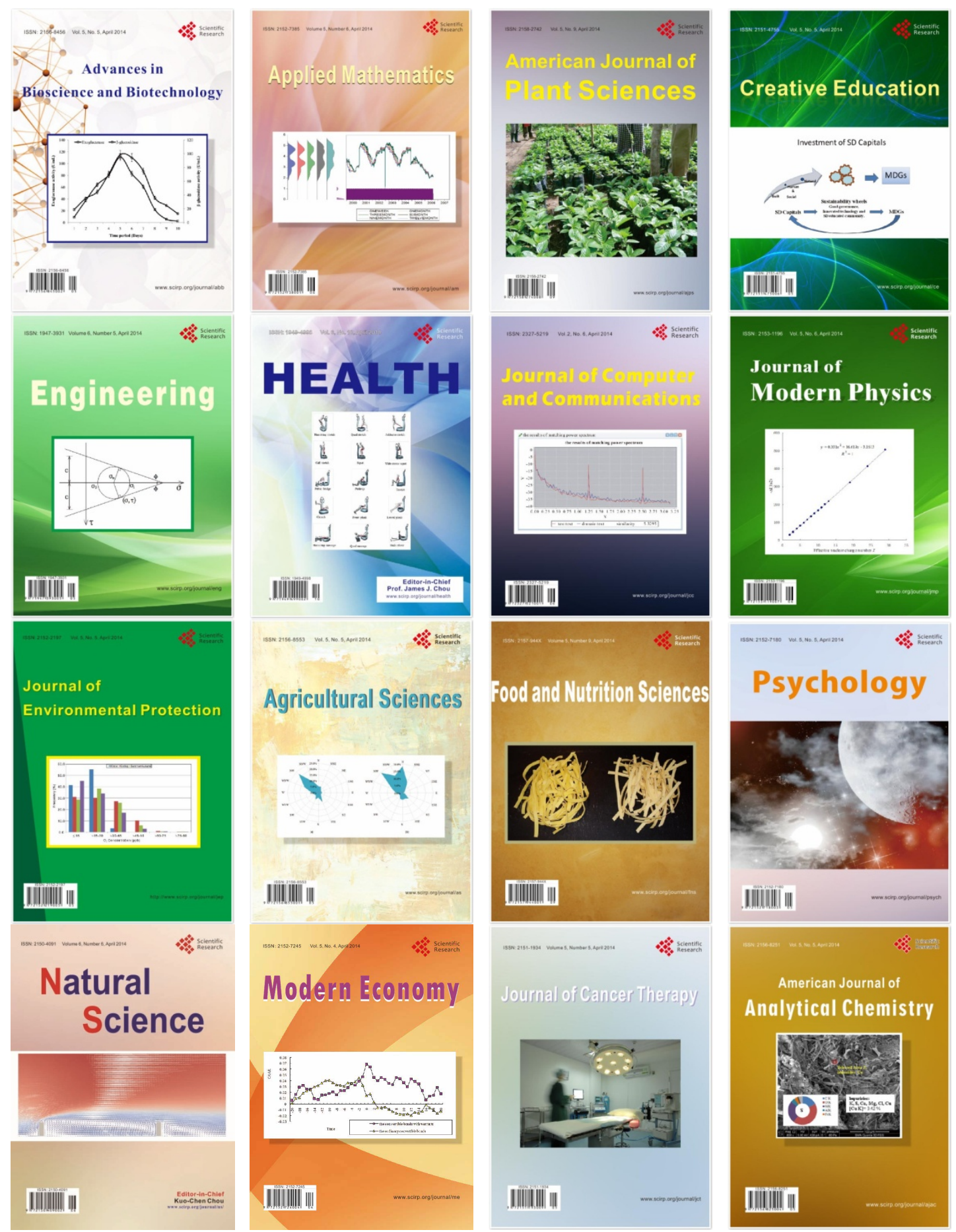